Article

\title{
New Beach Landscapes to Promote Social Distancing and Coastal Conservation during and after the COVID-19 Pandemic
}

\author{
Patricia Moreno-Casasola $^{1}\left(\mathbb{D}\right.$, Marisa Luisa Martínez ${ }^{1, *}$ (D) and Debora Lithgow ${ }^{2}$ \\ 1 Red de Ecología Funcional, Instituto de Ecología, A.C. (INECOL), Xalapa 91073, Mexico; \\ patricia.moreno@inecol.mx \\ 2 Red de Ambiente y Sustentabilidad, Instituto de Ecología, A.C. (INECOL), Xalapa 91073, Mexico; \\ debora.lithgow@inecol.mx \\ * Correspondence: marisa.martinez@inecol.mx
}

check for updates

Citation: Moreno-Casasola, P.; Martínez, M.L.; Lithgow, D. New Beach Landscapes to Promote Social Distancing and Coastal Conservation during and after the COVID-19 Pandemic. Sustainability 2021, 13, 6268. https://doi.org/10.3390/ su13116268

Academic Editors:

Thomas Panagopoulos,

Bruno Marques, Krzysztof Herman, Agnieszka Olszewska-Guizzo and Marc A. Rosen

Received: 20 April 2021

Accepted: 26 May 2021

Published: 1 June 2021

Publisher's Note: MDPI stays neutral with regard to jurisdictional claims in published maps and institutional affiliations.

Copyright: (c) 2021 by the authors. Licensee MDPI, Basel, Switzerland. This article is an open access article distributed under the terms and conditions of the Creative Commons Attribution (CC BY) license (https:// creativecommons.org/licenses/by/ $4.0 /)$.

\begin{abstract}
The Coronavirus disease 2019 (COVID-19) is a pandemic that has altered practically all human activities worldwide. Since the pandemic started at the beginning of 2020, infections have fluctuated drastically over time. It is difficult to predict how this situation will evolve in the coming months/years or when a return to some semblance of 'normal' activity might occur. Because of global lock-up and distancing measures, the beaches, otherwise filled with tourists, first emptied and then had a reduced density of visitors owing to a wide variety of social-distancing measures. Therefore, new safety protocols need to include a wide range of aspects, such as epidemiological conditions, socioeconomic realities, and ecological contexts in which the pandemic occurs. Here, we propose new nature-based landscapes for sandy beaches to help maintain the social distancing of beach visitors while beaches and dunes are restored. When sufficient sediment is available, the maintenance and restoration of healthy beaches with incipient dunes and vegetation will help reduce contagion, promote human health, and recover natural ecosystems.
\end{abstract}

Keywords: coastal management; incipient dunes; dunes; tourism; nature-based social distancing

\section{Introduction}

Since its outbreak in December 2019, the new coronavirus (SARS-CoV2) causing acute respiratory syndromes has generated unparalleled impacts worldwide. The medical, social, and economic shocks have affected most countries [1], and probably the impacts of the pandemic will last for years to come. As of 5 May 2021, the confirmed number of COVID-19 cases had reached 155 million, a total of 3.2 million deaths, and 133 million recovered globally [1]. To stop the spread of this virus and protect the most vulnerable people, strict quarantine measures, a generalized lockdown, and regulated attendance to public spaces with massive participation, such as the beach, have been implemented worldwide [2,3]. As the pandemic continued and evolved, a collapsing economy and social pressure due to canceled tourism [4] forced the authorities to open the beaches gradually. According to decisions made by local authorities, only restricted activities such as leisure, individual exercise, sunbathing, and swimming are allowed. A social distance policy has been enforced, and groups of visitors are restricted to a reduced number ranging (in Mexico, for example) from 2 to 10 [5], with limited permanence to render others the opportunity to use the beach, depending on local conditions and decision-makers. Suddenly, the beaches had sharp lower capacity limits [5]. Frequently, these decisions are difficult to implement.

As the pandemic continued, and with the progressive removal of lockdown restrictions, several alternatives for social distancing were provided for beachgoers by the authorities. These included different options that ranged from the placement of bunks and beach umbrellas at the indicated distance, setting physical limits with ropes and even fences and huts (Figure 1). More drastic measures involved the need to make reservations to attend 
the beach in, for example, Spain [3,6], Italy [7], and Argentina [8]. These guidelines may seem relatively simple to implement, but are they?
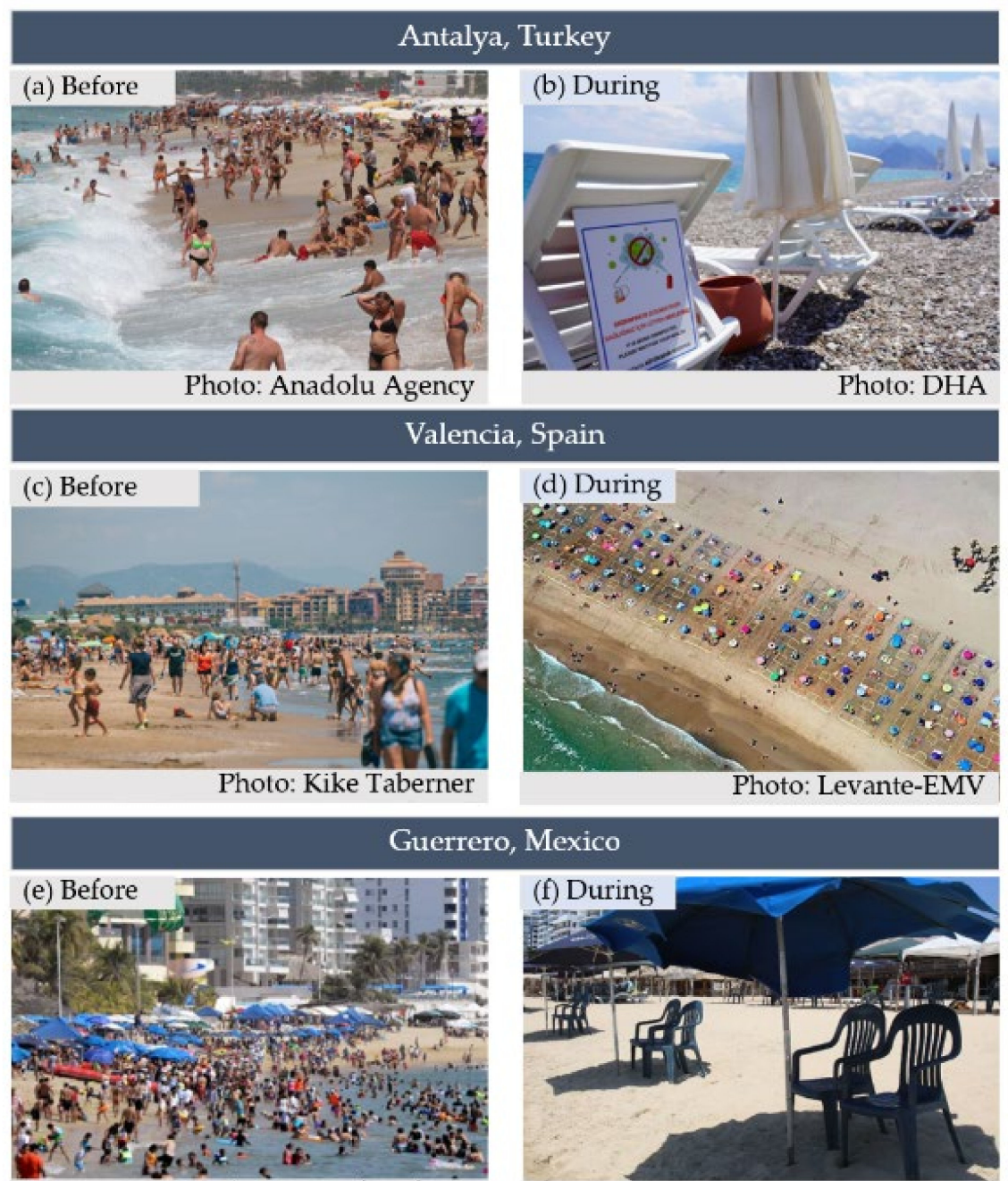

Photo: Martín Gómez

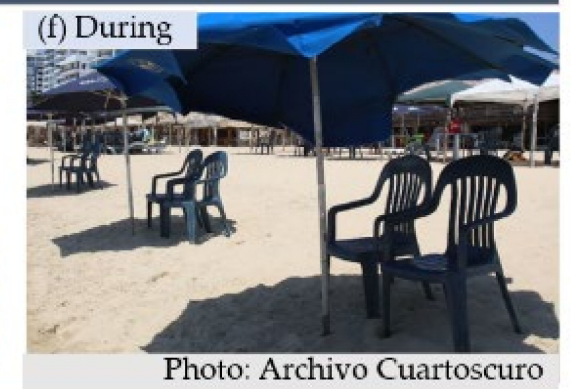

New rules of social distancing to attend the beach worldwide

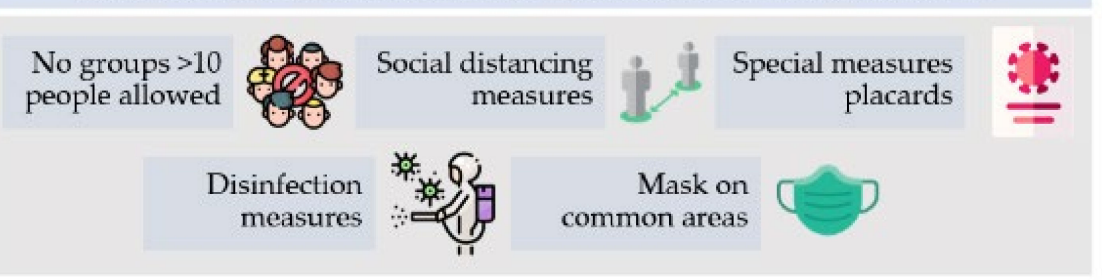

Figure 1. New rules of social distancing to attend the beach worldwide. Examples of spatial distribution of visitors in different tourist destinations before (typically crowded) and during the pandemic: (a) Antalya, Turkey before the pandemic; (b) Antalya, Turkey during the pandemic; (c) Valencia, Spain before the pandemic; (d) Valencia, Spain, during the pandemic; (e) Guerrero, México before the pandemic and (f) Guerrero, México, during the pandemic. Pictures during the pandemic highlight the social distancing measures. The sign with the new hygiene protocol is shown. (Photos from internet: Turkey [9,10], Spain [11,12], and Mexico [13,14]).

The pandemic has boosted research in many aspects and has flooded the scientific literature with publications focused on COVID-19. For instance, in the Web of Science database (consulted 1 May 2021), 102,816 articles on COVID-19 have been published (16 in 2019; 77,882 in 2020 and 24,918 in 2021 so far). For obvious reasons, most of them focus on 
medical findings and health-related actions (more than 30,000 articles), whereas very few (30) mention the beach. Even in these studies, health risks are a primary issue [4,15-18], and only one performed an ethnographic analysis of the emotional impact of restrictive beach access signs on the population [19]. A few have focused on pollution [20,21], environmental education and teaching [22,23], fisheries [24], environmental issues [25,26]. Studies dealing directly with beach tourism have addressed social media [27], local tourism networks [28], one-day tours [29], and the carrying capacity of the beach [2]. New publications regarding the COVID-19 pandemic and coastal management are currently underway. In these new studies, the topics addressed remain very diverse and cover, for example, the behavior and perception of beachgoers [30,31]; the pandemic and coastal erosion [32]; and management strategies which, again, involve estimates of the maximum number of visitors allowed $[3,8]$; signaling [33].

Indeed, similar to other aspects of the society affected by the pandemic, it is still necessary to assess the impact that the COVID-19 outbreak has had on our beaches. Examples are the effects of the release of human pressure on the coast, which have been observed through the sightings of endangered species (such as jaguars, leatherback turtles, great curassow birds, crocodiles, and dolphins) on empty and otherwise human-packed Mexican beaches and coastal cities [34]. In addition, the generalized lockdown of humans provided wildlife and natural ecosystems (for example, beaches and coastal dunes) with an unprecedented opportunity to recover from human pressure $[26,35,36]$.

As the pandemic advances and new information was published, it is now known that the outdoor risk of COVID-19 contagion is orders of magnitude lower than indoor [37]. These observations include coastal environments, such as public beaches, where exposure to COVID-transmission is reduced because respiratory droplets are dispersed through regular airflow [30]. Thus, urban beaches can be even more attractive places for leisure and recreation, given the restricted mobility we still have, more than one year after the pandemic onset $[30,38]$. New strategies have to be designed and tested to determine if they help create improved ad hoc schemes for coastal management. Thus, the opportunity to implement a social distancing program while protecting and restoring sandy beaches and coastal dunes are now at hand. This proposal explores a new alternative to promote social distancing at the beach (especially in urban locations) while coastal dunes and plant species are restored and protected. The proposal has not been tested yet but aims to offer new nature-based alternatives, which will promote the health of beachgoers while increasing the scenic beauty and protecting native plant species, frequently trampled on, and destroyed by tourists. The proposal will also help link two of the most significant problems facing humanity today: pandemics and the impact of climate change.

\section{Materials and Methods}

2.1. Creating New Beach Landscapes to Promote Social Distancing during and after the COVID-19 Pandemic

Recently, coastal protection strategies have profited from ecosystems' natural functioning, containing species with specific growth forms and tolerances to environmental constraints. These species can modify the local physical environment by trapping and stabilizing sand, so the beach elevation increases, and subsequently, the impact of storms and waves is mitigated [39]. Furthermore, the latest studies have demonstrated that waveinduced beach and dune erosion can decrease by up to $64 \%$ in the presence of beach plants growing on dunes [40]. The above implies that coastal dunes and beach plants offer sustainable and cost-effective coastal protection solutions.

In addition to the benefits of providing protection, coastal dunes can also help humans to go back to the beach during and after the pandemic by promoting an effective social distance. This proposal suggests a nature-based social distancing scheme supported by the environmental heterogeneity and dynamics of the beach and incipient dunes and their accompanying vegetation. Our proposal suggests using incipient (or embryo) dunes that will help promote the necessary social distancing. Furthermore, these actions will help protect local native plant species and natural dynamics while increasing the scenic beauty 
with a far more enjoyable environment than ropes or fences (Figure 1). This proposal can also help visitors understand beach functioning, enjoy natural scenic beauty, and comprehend the relevance of conservation and protection actions.

The proposal's effectiveness in terms of how the beaches should be managed relies on understanding (a) how beach heterogeneity and dynamics can help promote social distancing, (b) how incipient dunes are built, and (c) the role of plants in dune formation. Adequate information regarding these new (and old) strategies is fundamental. An example is presented in Figure 2. Beaches in distant locations, mostly well preserved and with no human impact, may contain incipient dunes, foredunes, and stabilized dunes, which are natural elements on the beachscape (Figure 2a). These geomorphological features tend to disappear in urban and suburban beaches, where dunes are flattened, vegetation is eliminated, and instead, different facilities are offered to visitors (Figure $2 b$ ). In a new beachscape in urban locations, when sufficient sediment supply is available, a naturalized beach with incipient dunes and vegetation will create a more heterogeneous beachscape. A heterogeneous beach will promote social distancing, help preserve native species, and enhance scenic beauty with more natural elements (Figure 2c). In Mexico, for example, the beaches with incipient dunes formed by Croton punctatus along the Gulf of Mexico (Doña Juana) are depicted in Figure 3. Beach umbrellas are located hypothetically between the incipient dunes to promote social distancing enforced by topography and vegetation.

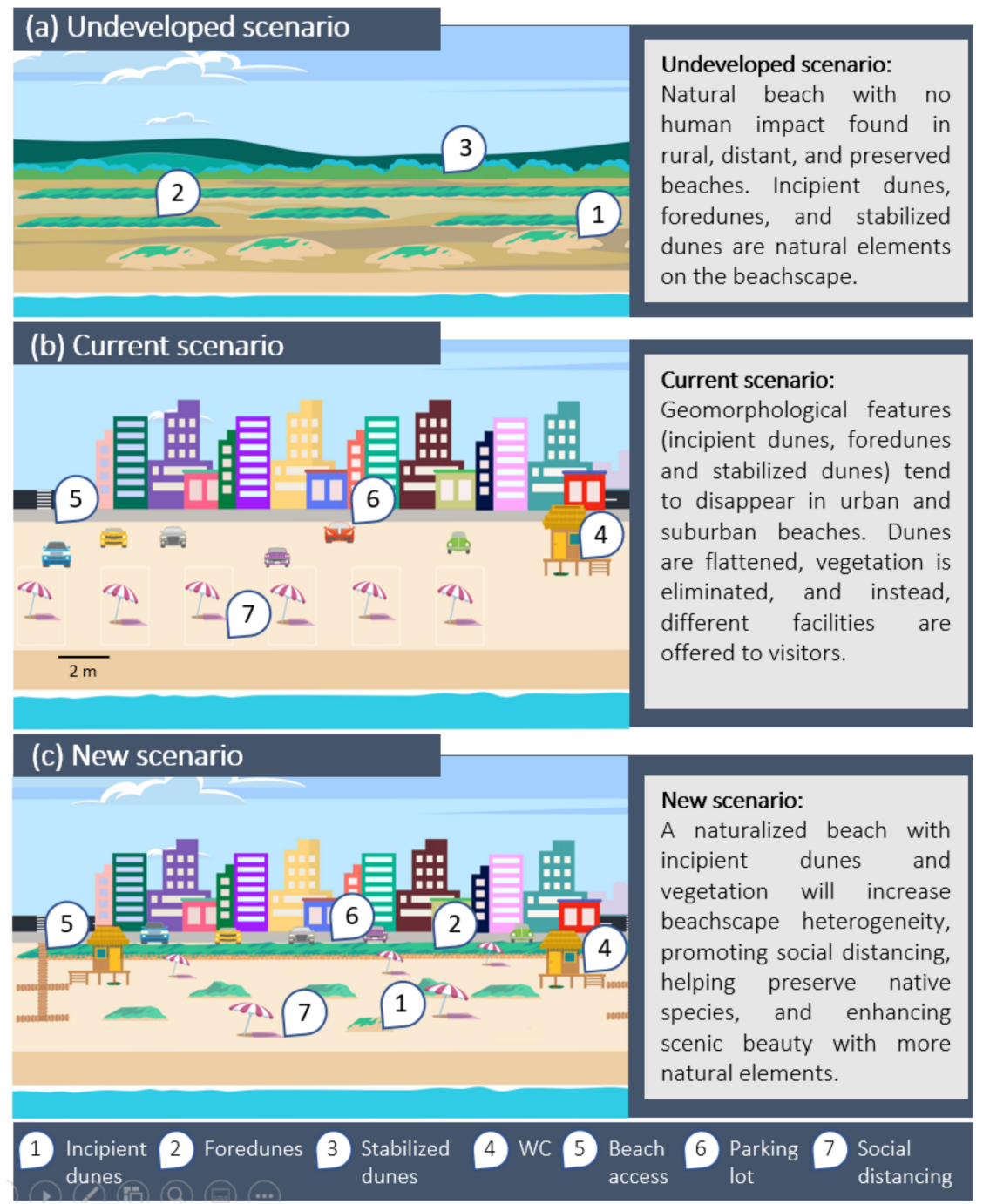

Figure 2. Different alternatives for beach management; (a) natural setting in rural or distant locations; (b) degraded urban beaches; (c) naturalized urban beaches. 


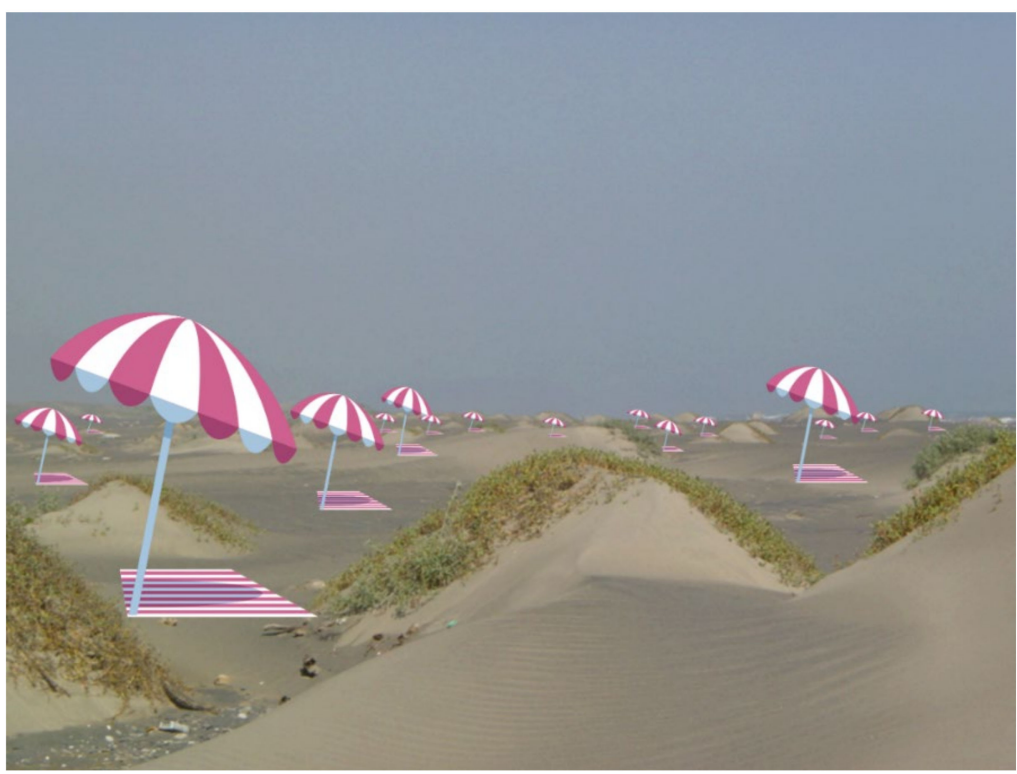

Figure 3. The hypothetical distribution of beach goers interspersed with incipient dunes.

\subsection{Implementing New Measures for Beach COVID 19 Management-A Case Study of Mexico}

This study focuses on an incipient dune strategy to promote social distancing in the COVID-19 pandemic through a nature-based solution. Additional benefits include the restoration of coastal dunes and native plants. Furthermore, given adequate conditions for building incipient dunes, this model could benefit most beaches worldwide, even after the cessation of anti-epidemic measures.

The Mexican coasts offer 270 beaches for recreation, where sanitary facilities and amenities are available for tourists [41] and host a broad diversity of ecosystems such as seagrasses, coral reefs, mangroves, and coastal dunes. The geomorphological heterogeneity includes various sandy beaches, cliffs, and rocky shores, although sandy coasts are the most abundant. Mexican beaches' economic relevance is significant for international and national tourism, contributing to $9 \%$ of the national GDP [42]. Except for Mexico City, the destinations most frequently visited by tourists, both national and international, are located on the coasts and include sandy beaches [41]. The above shows the importance of reactivating beach tourism with adequate measures that guarantee visitors' and workers' health.

Although implementing new measures to safeguard people's health from attending the beach seems to be a straightforward action, it will vary according to the location. Indeed, the beaches are anything but homogeneous. They vary in terms of their geomorphological attributes, local or visiting biota (abundant or scarce), and socioeconomic characteristics. The allowed carrying capacity of Mexican beaches is also heterogeneous, and regulations have become stricter, with a new classification according to the permitted beach occupation. Mexican beaches are now classified as urban-suburban (with one person $/ 5 \mathrm{~m}^{2}$ ); rural (one person $/ 7.5 \mathrm{~m}^{2}$ ); remote (one person $/ 10 \mathrm{~m}^{2}$ ); and aimed at nature protection (no human activities allowed) [5]. Very recently, on 21 October 2020, a new presidential decree was published stating that all beaches in Mexico are public and should have access to visitors [43]. This resolution means that the number of visitors visiting the beach will increase, for example, in touristic areas such as the Riviera Maya [44].

The diverse array of conditions on Mexican beaches results in different types of visitors, authorities, stakeholders, rules, facilities, and infrastructure (see detailed information of the most relevant beaches each coastal state has in [45]). The preferences of national and international beach tourists are also different. For instance, national tourists mostly visit Acapulco (on the Pacific coast) and Veracruz (in the Gulf of Mexico), whereas international tourists prefer Cancun (in the Mexican Caribbean), Acapulco, and Puerto Vallarta (both on 
the Pacific coast) [46]. In consequence, enforcing social distancing may be complicated and site-dependent. Knowledge, understanding, and comprehension of what COVID-19 means and the importance of complying with safety recommendations and implementation vary depending on cultural and local socioeconomic contexts. For example, in Latin American countries such as Mexico, hotels in urban and suburban tourism poles are generally built directly at the back of the beach. Several services, such as beach umbrellas, bunks, drinks, and group activities, among others, are offered to tourists by the hotel's staff, as well as street vendors that depend on this income [47]. Maintaining the new pandemic rules for social distancing to enforce low-density occupations depends on the supervision by authorities and the enforcement by staff working at the beach, and an understanding of the health problem by beach visitors.

In rural and remote beaches, the situation is different. Frequently, local authorities do not take responsibility for adequate beach management (i.e., cleaning the beach, hiring lifeguards, providing parking and sanitary facilities, etc.). Instead, governmental efforts mainly focus on approving permits and collecting taxes for opening facilities such as hotels and restaurants near the beach. The hotel licensing permit is the only activity specified and regulated in the Mexican law for beach management (article 119, [48] applied by ZOFEMAT-Maritime Terrestrial Federal Zone, in Spanish). Local inhabitants have heard of COVID-19 and have even seen people dying. Many believe they can cure the disease through their usual methods (using native plants, medicines for treating colds, or pneumonia). Furthermore, inhabitants and visitors tend to avoid face masks because of the breathing difficulties and discomfort of wearing them in the hot and humid weather of tropical beaches. In general, no indication (signs) of the new safety measures (or any warning, as a matter of fact) is offered in these rural and remote beaches.

In brief, the varying conditions and contexts of the Mexican beaches probably occur in other tropical coasts. They show that returning to the beach should be tackled in diverse ways, depending on the local conditions. These new strategies should be easily applied and should not represent a yearly economic burden.

\subsection{Databases Used to Build a Proposal to Create New Beach Landscapes to Promote Social Distancing during and after the COVID-19 Pandemic}

The proposal aims at creating new multi-functional beachscapes in Mexico that could help enhance social distancing during and after the COVID-19 pandemic and promote the recovery of dune diversity. Building new beachscapes to restore urban beaches and recover degraded or lost coastal dunes and accompanying vegetation needs knowledge on the interaction between plants and dunes and the local conditions that will help promote such dune-building actions. To achieve this, we combined previously published information on Mexican beaches and coastal dunes attributes, beach and dune flora, and plant growth forms (Figure 4). With this, we had sufficient information to explore this proposal further.

The extent, spatial distribution, and condition of coastal dunes along the coasts of Mexico were described in detail by [49] (information is available upon request), based on field information and aerial images. In addition, the extensive work by several authors (see references cited by [49-52]. In [50,52], the flora from the Mexican beaches and coastal dunes was sampled throughout Mexican coasts and resulted in a detailed revision of plant specimens, which safeguards herbaria collections from several Mexican institutions. Finally, we also used published data plant functional types, especially those with the ability to tolerate sand accretion [53-55]. With this, we had sufficient information on which species would be adequate for building and restoring coastal dunes, considering the heterogeneity and diversity of Mexican beaches. 


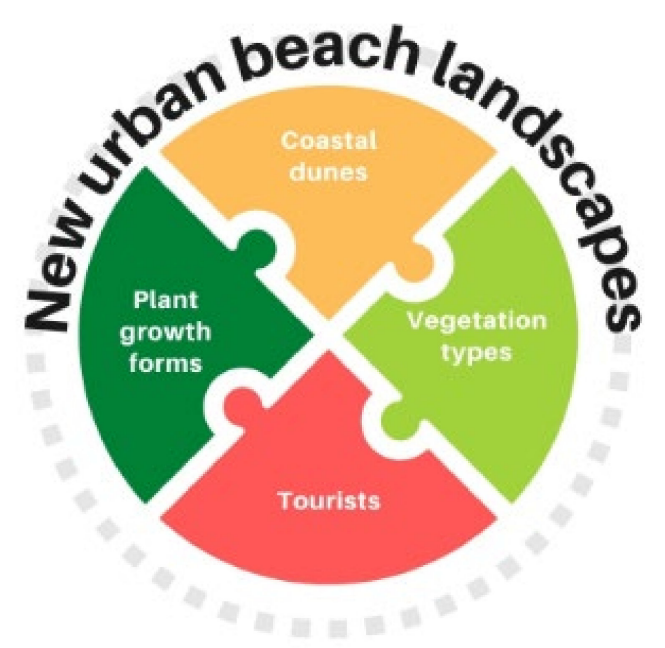

Figure 4. The elements for building new urban beach landscapes that will help maintain social distancing and preserve natural ecosystems.

\section{Results}

\subsection{Beach Heterogeneity and Dynamics Can Help Promote Social Distancing}

Incipient dunes and foredunes are essential elements on most sandy beaches, rendering the coast and beach as highly heterogeneous and dynamic environments. The size and morphology of coastal dunes depend on the complex interaction between sediment supply, the nearshore and beach geomorphology, and predominant winds [56]. Foredunes develop at the rear of the backshore environments (landward of the active beach) and are classified into three main types: incipient foredunes, established foredunes, and relict foredunes [57]. Incipient foredunes represent the initial stage of a foredune. They are located above the high spring tide mark and are formed because of obstacles that reduce wind-flow velocities and result in sediment accumulation. Vegetation is the most common obstacle contributing to the formation of incipient dunes and foredunes [57] and determines the dunes' shape.

Incipient dunes can be ephemeral features because they can be eroded or entirely removed by severe storm events. Still, given sufficient sand supply, they are rebuilt again as the process restarts. In time, as incipient dunes accumulate sand and increase in height, and as vegetation cover increases, the dunes coalesce and become larger established foredunes [57]. This repetitive cycle constitutes the dynamics of sandy beaches and helps protect the coasts from erosion and flooding.

In Mexico, for example, the beaches with incipient dunes formed by Croton punctatus along the Gulf of Mexico (Doña Juana) are depicted in Figure 4. Beach umbrellas are located hypothetically between the incipient dunes to promote social distancing enforced by topography and vegetation. It is essential to avoid walking on the dunes and destroying them. Instead, flat areas between the dunes should be used to walk along the beach.

\subsection{Building Incipient Dunes}

Dunes can be built naturally by merely enabling or facilitating natural sand accumulation processes to occur, or they can be constructed artificially through different methods, including shovels and machinery. The first, more natural option should be promoted, whereas the second should only be used in extreme situations when natural sand accumulation processes are unlikely to occur [58].

Several biophysical features are relevant for building an incipient dune: the distance of the water table to the surface of the sand, the availability of sediment supply, the adequate fetch to transport sand, and the minimum distance of the plants to the shore that is necessary for their survival. For example, in field conditions, [59] measured differences in dunebuilding abilities between three types of dune grasses, whose ability to survive were also affected by distance to the shore and elevation. Similarly, [60] observed that the distance 
to the shore and the elevation above sea level also determined the landscape position of several beach dune species and, consequently, the spatial distribution of incipient dunes built around these plants.

When beaches have sufficient sediment supply, it is possible to use specific plant species combined with obstacles (such as pieces of tree trunks, branches, parts of wood fences, etc.) to promote sand accumulation and formation of incipient dunes. Sand fences are frequently installed in the United States and Europe and are commonly used to control the flows of air, water, sediments, people, and animals. The barrier effect of sand fences induces the accumulation of sediments and propagules and results in the creation of new landforms (incipient dunes) [58].

\subsection{The Role of Plants in Dune Formation}

Planting beach and dune plants has been frequently conducted to stabilize the sand and create dunes where necessary $[58,61]$. The tolerance to burial by sand is a unique adaptation of psammophilous plants, which naturally promotes dune formation on sandy beaches. Therefore, only a handful of species are dune-builders.

Plant density, morphology, and architecture determine dune initiation and shape. For example, [62] observed that taller and larger dunes are formed by taller plants, while erect grasses produced more elongated dunes, and the smallest plants create the lowest dunes. Two grass species have been frequently used in Europe (Ammophila arenariamarram grass) and the USA (A. breviligulata - beach grass) to trap sand, thereby building dunes [63]. Specifically, marram grass has been widely used to stabilize and establish dunes for forestry plantings, property protection, and erosion control. However, outside its natural distribution range (USA, South Africa, New Zealand, and Australia), this exotic grass can become an invasive plant by competing and displacing native plant communities and altering the dune habitats with further consequences for invertebrate communities and bird species [64]. These and other findings have demonstrated the need to use local native plants to build new dunes and change the beach's landform when necessary. Therefore, the choice of plants to be used for dune-building is essential, as they should be native dune builders with the natural ability to accumulate sand. It is also necessary to consider that the geographic distribution of dune-building plants will affect dune shape and type [65].

Previously published studies (see references cited by [49-52] have revealed a total of 2075 plant species listed for the Mexican sandy coasts. This number represents a relatively high percentage because the total surface of coastal dunes in Mexico (800,000 ha) represents 0.4 of the entire territory. However, this seemingly insignificant surface holds $12 \%$ of the Mexican flora.

We extracted only those species with sand-binding dune-building abilities from this long list, which could potentially be used for building incipient dunes and foredunes. Then, a new condensed list with 45 plant species that grow on Mexican beaches and that can potentially be used for dune-building purposes was elaborated. We considered previous information on vegetation composition and structure described for each coastal state in Mexico [49], a review of the published literature describing the dune-building capacity of beach plant species [59,66-70], and our unpublished field observations (Table 1). The species included in this list belong to 20 families. The families with the largest number of species are Asteraceae and Poaceae (6 species), Amaranthaceae (5), Aizoaceae, and Fabaceae (each with 4), and Euphorbiaceae (3). These species occur in the five floristic regions into which the Mexican coastal flora has been classified [49]. In the current study, we combined the 18 species listed for the North Pacific and Gulf of Cortes region because they share many species. We then included 12 species from the South Pacific, 16 from the Gulf of Mexico, and 20 from the Caribbean (Table 1).

The choice of plants determines the shape and size of the dune because species differ considerably in their sand binding ability and the type of dune formed around them. Dunebuilding species from Mexican beaches grow in a wide variety of forms (Table 2). Some grasses are stoloniferous, while others grow in culms and develop rhizomes. Creepers are 
also abundant, and, unlike psammophilous plants from temperate latitudes, some shrubs and subshrubs are also tolerant of burial and are effective dune builders. The shapes of the dunes formed around these plants with diverse growth forms are also variable (Figure 5).

The first model on sand accumulation around a plant was based on Ammophila arenaria [71]. However, new models are necessary for plants with growth forms other than tall culms with rhizomes, such as A. arenaria [72] (Table 2). Like A. arenaria, tall tropical grasses with culms and rhizomes (i.e., Uniola paniculata) form high dunes covering large surfaces. In turn, the dunes around stoloniferous grasses (Sporobolus virginicus) are small. Herbs can also be effective sand binders, especially when they grow clumped together (i.e., Cakile spp.). When the branches of herbaceous plants are prostrate (creeping herbs Ipomoea pescaprae), dense vegetation mats can spread over the sand's surface, and the dunes are short but wide. Shrubs and subshrubs can elongate their branches and protrude from the sand forming relatively tall dunes (Croton punctatus). Some shrubby plants' stems can produce roots when in contact with the sand, promoting sand accumulation. In addition to plants role in building different dunes, the shape and size of the dunes will also vary depending on local conditions such as the type of sand, size of the sand grains, and predominant wind regime. For example, the dunes formed around Scaevola plumieri are large on the Pacific coast and much smaller in the Caribbean.
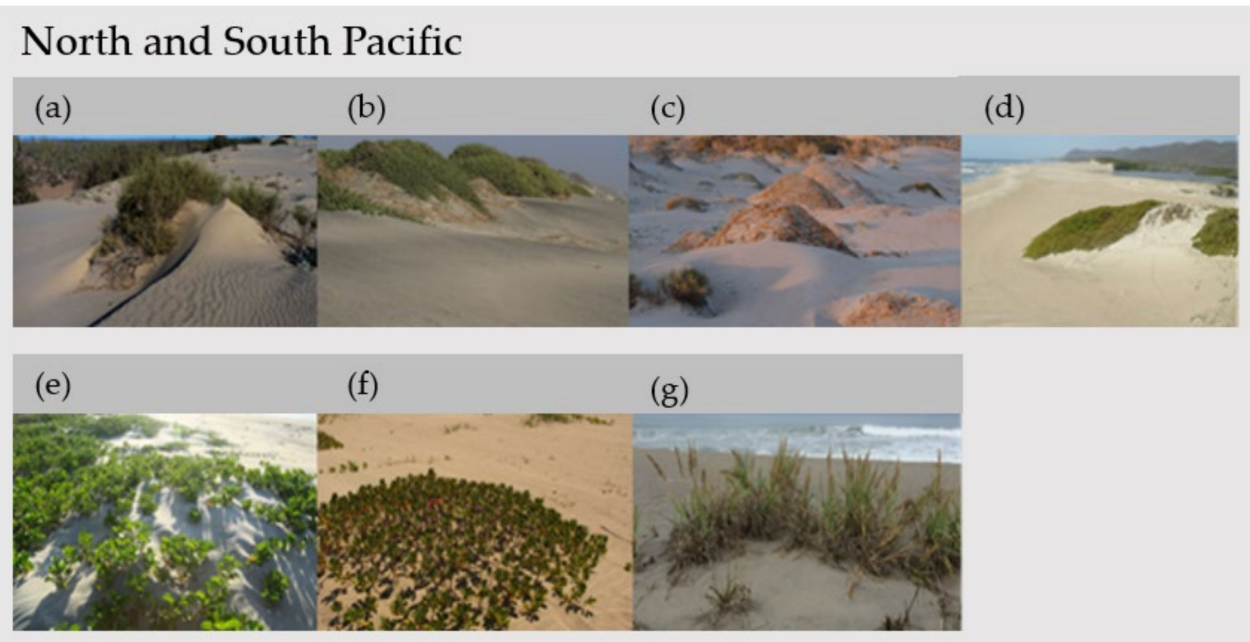

\section{Gulf of Mexico and Caribbean Sea}
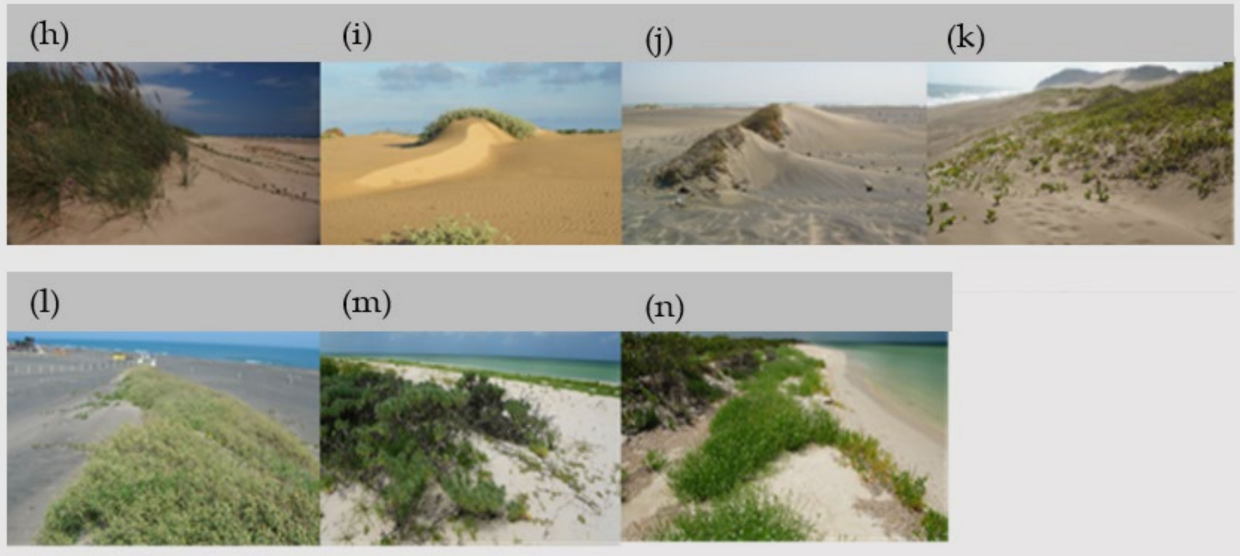

Figure 5. Different species form incipient dunes in the various regions along the coasts of Mexico. North Pacific: and South (a) Atriplex canescens, (b) Abronia maritima, (c) Sesuvium portulacastrum, with Abronia maritima; (d) Scaevola plumieri, (e) Ipomoea pes-caprae, (f) Scaevola plumieri, (g) Uniola pittieri. Gulf of Mexico and Caribbean: (h) Uniola paniculata, (i) Croton punctatus, (j) Sesuvium portulacastrum, (k) Ipomoea pes-caprae, (1) Croton punctatus with Palafoxia lindenii (m) Tournefortia gnaphalodes, and (n) Cakile spp. (Picture credits: Gerardo Sánchez Vigil). 
Table 1. Dune-building and sand-binding species list, including family and the distribution in the Mexican coastal floristic regions. * Type of species refers to those recognized by [52] as mainly coastal dune species. ${ }^{* *}$ Espejel et al. [52] did not mark Suriana maritina as a coastal dune species, but we considered this species coastal in this study. ${ }^{* * *}$ Exotic plants that can become invaders.

\begin{tabular}{|c|c|c|c|c|c|c|}
\hline Family & Species & $\begin{array}{l}\text { Type of } \\
\text { Species }\end{array}$ & $\begin{array}{l}\text { North Pacific \& } \\
\text { Cortes Sea }\end{array}$ & $\begin{array}{l}\text { South } \\
\text { Pacific }\end{array}$ & Caribbean & $\begin{array}{l}\text { Gulf of } \\
\text { Mexico }\end{array}$ \\
\hline Nyctaginaceae & Abronia maritima Nutt. ex S. Watson & * & 1 & 1 & & \\
\hline Amaranthaceae & Alernanthera flavescens Kunth & & & & 1 & \\
\hline Amaranthaceae & Amaranthus greggii S. Watson & * & & & 1 & 1 \\
\hline Asteraceae & Ambrosia dumosa (A. Gray) Payne & & 1 & & & \\
\hline Asteraceae & Ambrosia hispida Pursh & * & & & 1 & \\
\hline Poaceae & Arundo donax $\mathrm{L}$. & *** & & & 1 & \\
\hline Amaranthaceae & Atriplex barclayana (Benth.) D. Dietr. & & 1 & & & \\
\hline Amaranthaceae & Atriplex canescens (Pursh) Nutt & & & & 1 & \\
\hline Amaranthaceae & Atriplex leucophylla (Moq.) D.Dietr. & & 1 & & & \\
\hline Bataceae & Batis maritima $\mathrm{L}$. & & 1 & & & \\
\hline Fabaceae & Caesalpinia bonduc (L.) Roxb. & * & 1 & & & \\
\hline Brassicaceae & Cakile edentula (Bigelow) Hook. & * & & & 1 & \\
\hline Brassicaceae & Cakile maritima Scop. & $* * *$ & 1 & & & \\
\hline Fabaceae & Canavalia rosea $(S w$.$) DC.$ & * & & 1 & 1 & 1 \\
\hline Fabaceae & $\begin{array}{c}\text { Chamaecrista chamaecristoides (Collad.) } \\
\text { Greene }\end{array}$ & * & & & 1 & 1 \\
\hline Euphorbiaceae & Cnidoscolus texanus (Müll. Arg.) Small & & & 1 & & \\
\hline Polygonaceae & Coccoloba uvifera (L.) L. & * & & & & 1 \\
\hline Euphorbiaceae & Croton punctatus Jacq. & * & & & 1 & 1 \\
\hline Ephedraceae & Ephedra trifurca Torr. ex S. Watson & & 1 & & & \\
\hline Rubiaceae & Ernodea littoralis Sw. & * & & & 1 & \\
\hline Euphorbiaceae & Euphorbia mesembryanthemifolia Jacq & & & & 1 & \\
\hline Frankeniaceae & Frankenia palmeri S. Watson & & 1 & & & \\
\hline Convolvulaceae & Ipomoea imperatii (Vahl) Griseb. & * & & & 1 & 1 \\
\hline Convolvulaceae & Ipomoea pes-caprae (L.) R. Br. & * & 1 & 1 & 1 & 1 \\
\hline Poaceae & Jouvea pilosa (J. Presl) Scribn. & * & 1 & 1 & & \\
\hline Fabaceae & Marina maritima (Brandegee) Barneby & * & 1 & & & \\
\hline Aizoaceae & Mesembryanthemum crystallinum L. & $* * *$ & 1 & & & \\
\hline Onagraceae & Oenothera drummondii Hook. & * & & & & 1 \\
\hline Nyctaginaceae & Okenia hypogaea Schltdl. \& Cham. & * & & 1 & 1 & 1 \\
\hline Asteraceae & Palafoxia lindenii A.Gray & * & & & & 1 \\
\hline Asteraceae & Palafoxia texana DC. & & & & & 1 \\
\hline Poaceae & Panicum amarum Elliott & * & & & & 1 \\
\hline Asteraceae & Pectis arenaria Benth. & & 1 & 1 & & \\
\hline Portulacaceae & Portulaca pilosa $\mathrm{L}$. & & 1 & & & \\
\hline Goodeniaceae & Scaevola plumieri (L.) Vahl & * & & 1 & 1 & \\
\hline Aizoaceae & Sesuvium portulacastrum (L.) L. & & 1 & 1 & 1 & 1 \\
\hline Aizoaceae & Sesuvium verrucosum Raf. & * & 1 & & & \\
\hline Asteraceae & Solidago sempervirens L. & & & & & 1 \\
\hline Poaceae & Sporobolus virginicus (L.) Kunth & * & 1 & 1 & 1 & 1 \\
\hline Surianaceae & Suriana maritima $\mathrm{L}$. & $* *$ & & & 1 & \\
\hline Boraginaceae & $\begin{array}{l}\text { Tournefortia gnaphalodes (L.) R. Br. ex } \\
\text { Roem. \& Schult }\end{array}$ & * & & & 1 & \\
\hline Aizoaceae & Trianthema portulacastrum $\mathrm{L}$. & & & 1 & & \\
\hline Zygophyllaceae & Tribulus cistoides L. & & & & 1 & \\
\hline Poaceae & Uniola paniculata $\mathrm{L}$. & * & & & 1 & 1 \\
\hline Poaceae & Uniola pittieri Hack. & & & 1 & & \\
\hline
\end{tabular}


Table 2. Growth forms and types of dunes formed after the accumulation of sand.

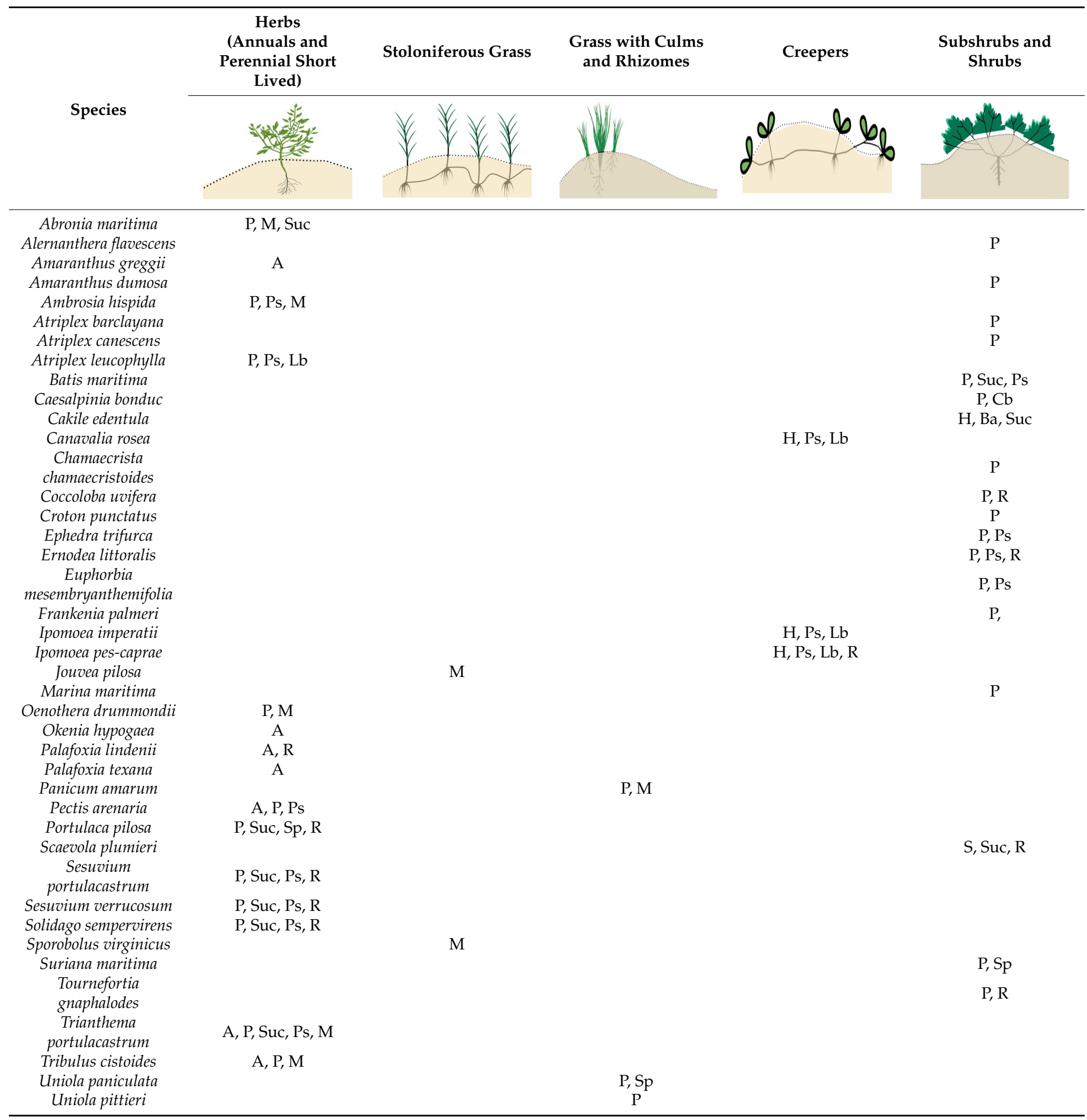

Five types of growth or models are shown. Exotic species were not included. A: annual, Ba: biannual, P: perennial, H: herbaceous, Suc: succulents, M: mat-forming, Ps: prostrate, Sp: spreading, Lb: long branches, Cb: climbing branches, R: rooting from stems touching the sand (data reanalyzed from [52]).

The vegetation that develops on the Mexican beaches and coastal dunes includes several dune-building plants, with different growth forms that vary significantly throughout the coast's $11,000 \mathrm{~km}$. In addition, dominant dune-building plants vary regionally (Figure 6), which should be considered when reconstructing dunes.

For instance, [52] synthesized all the information gathered regarding coastal dune vegetation in Mexico. These authors reveal a total of 2075 species growing on Mexican coastal dunes, which represent $8 \%$ of the total plant diversity in Mexico (23,791 species) [52]. 
This percentage is significant, given that the entire surface of coastal dunes in Mexico (800,000 ha) represents less than $1 \%$ of the Mexican territory. Specifically, in terms of dunebuilding species, the diversity of growth forms is also high, and it varies geographically. Herbaceous species are equally abundant in all regions, whereas shrubs are more abundant in the Caribbean and very low in the South Pacific. Creepers are scarce in the North Pacific and Cortes Sea.

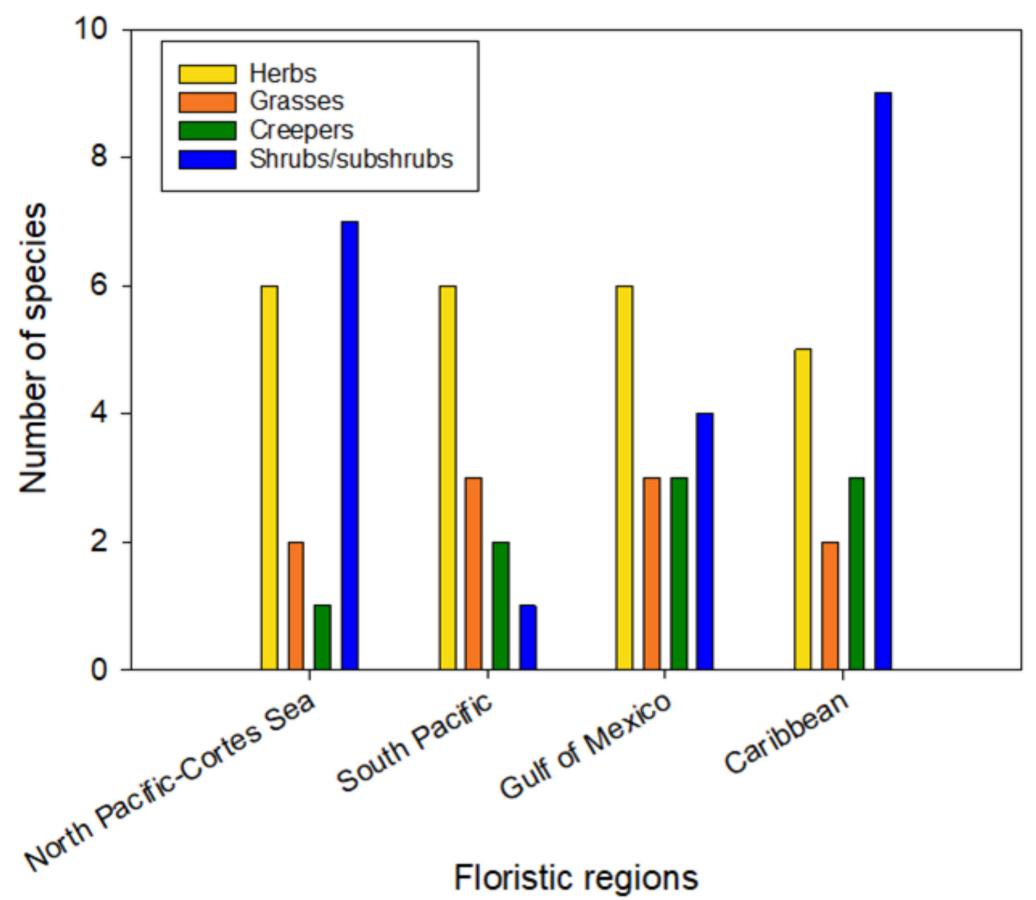

Figure 6. The number of dune-building species with different growth forms found in the four floristic regions of the Mexican coasts (Reanalyzed data from [50,52]).

\subsection{Distribution of Coastal Dunes in Mexico}

The wide variety of environmental conditions and plant species found along the coasts of Mexico also results in a considerable heterogeneity of dune forms [49]. These are distributed unequally among regions. In the inventory of Mexican of coastal dunes, [49] demonstrated that frontal dune plains and transgressive dunes are the most abundant dune types in the country. These authors mapped the different kinds of coastal dunes in the Mexican littoral, and with this information, we elaborated on Figure 7. Transgressive dunes are most abundant in the North Pacific and Cortes Sea (Figure 7), whereas parabolic dunes mainly occur along the Gulf of Mexico. Frontal dunes are relatively scarce. These results show the abundance of coastal dunes along Mexican coasts, and therefore, the possibility of building incipient dunes. However, local, more detailed studies would be necessary to create new beach landscapes, mainly on urbanized coasts.

In terms of beach and dune management and the need to promote nature-based social distancing, it is imperative to bear in mind the required size and type of dunes and the plants' aesthetics to be used to create adequate "natural beach separators." The plants used in dune-forming projects can be reproduced in rustic local greenhouses, from either seed or plant fragments that can resprout (for example, Sesuvium portulacastrum and Ipomoea pes-caprae, among others). In addition, existing dune types in each location (or expected dune types) will aid in deciding the types of dunes to be built for a nature-based social distancing. 


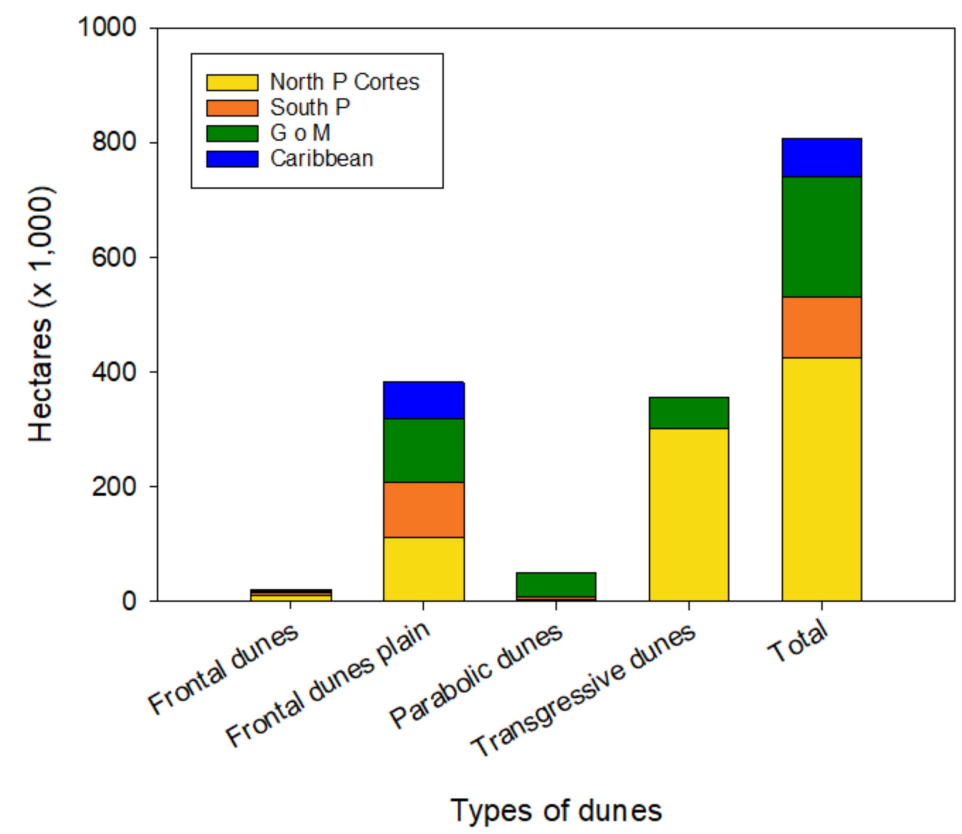

Figure 7. The distribution of dune types along the coasts of each floristic region in Mexico (Reanalyzed data from [49]).

\section{Discussion}

The COVID-19 outbreak has placed humans at stake. Many aspects of our society and human activities have mainly been affected and altered by the pandemic. Given this situation and the inability to predict this new condition's duration, we need to develop new strategies. During and after the pandemic, a unique opportunity opens and enables us to design and eventually test new ad hoc schemes for coastal management. These actions might be most relevant in urban locations, where the beaches are used the most and with the highest densities. When beach width and sediment availability are adequate, this proposal offers new alternatives that will help promote nature-based social distancing. Instead of flattening the dunes and eliminating vegetation, a more heterogeneous beach with dunes and plants will also provide natural scenic beauty while helping with the conservation and protection of coastal dunes and their biota.

Besides promoting social distancing and restoring and recovering coastal dunes, these actions may also help address beach erosion and sand loss, a worldwide concern [73]. It is the result in part of climate change and the consequent sea-level rise [74] and of bad management practices (see for example [75]). Despite the evidence indicating the urgency of promoting climate change mitigation actions, the current pandemic crisis has forced governments to stop investing in these strategies (climate change mitigation and adaptation) despite many papers calling for emergent measures [76], and a global crisis of shoreline erosion [77]. Considering the recent evidence showing that beach vegetation helps mitigate erosion [78], this proposal links human health, economic recovery, and beach management and conservation. This approach aims at constructing more sustainable coasts.

A first step towards implementing this nature-based social distancing and coastal dune conservation requires analyzing the natural distribution of coastal dunes and their accompanying dune-building plants [49]. This proposal shows that the distribution of different coastal dune types along the coasts of Mexico is very variable along the four floristic regions in which the Mexican coasts have been divided [52]. The largest surface of coastal dunes is found in the North Pacific and the Sea of Cortes, followed by the Gulf of Mexico and the Southern Pacific. The Caribbean coasts contain the most reduced surface of coastal dunes. Dune types also vary: transgressive dunes and foredunes predominant on the North Pacific and the Gulf of Cortes. Most parabolic dunes occur along the Gulf of 
Mexico. Foredunes are abundant in the Caribbean and southern Pacific. Thus, each region has its own set of incipient and foredunes with the accompanying flora that can be used or restored to implement this proposal's strategy [49]. Beaches that already have incipient dunes and foredunes should be conserved, with adequate actions and legal instruments. When the dunes are destroyed, restoration is another alternative [58].

Similar to dune types and their distribution throughout Mexico's coasts, the diversity of dune-building plants is relatively large. [52] mention 42 dune building species with heterogeneous distribution and the ability to form different dune types. Thus, the Mexican beaches' varying conditions and situations show that the promotion of a nature-based social distancing should be promoted differently, depending on the local conditions. These strategies can be applied with relative ease and should not represent a yearly economic burden to the authorities or owners so that the proposal is self-sustainable.

In addition to restoring and recovering coastal dunes, new policies that promote the conservation of these ecosystems are urgent, given the many ecosystem services provided by these ecosystems to society [79]. As degradation continues, the loss of ecosystem services will escalate. An excellent example of how effective protection policies help recover natural ecosystems is observed with mangroves in Mexico, which have resulted in a stable and even an increasing surface covered by these ecosystems [80]. A similar approach has to be followed regarding beach and dune conservation, which produces jobs and entertainment and protects from sea level rise.

\section{Caveats of the Proposal}

As with any proposal for new management schemes, our model does not come without limitations that point to future coastal research and management directions. The proposal of beachscape changes has not been subjected to verification of its effectiveness, and thus, several potential barriers might arise before adopting the incipient dune strategy. We will address several potential obstacles that are particularly relevant to consider.

First, building incipient dunes can be particularly challenging and needs knowledge and understanding of the dynamics of each beach [81]. It is essential to consider the biophysical attributes of each beach that will either facilitate or limit the possibility of building incipient dunes. These attributes include sufficient sediment supply, wind speed, depth of the water table, and available native dune-building plants [58]. The different types of incipient dunes depend on specific growth form, growth rate, density, and architecture of dune-building species [82,83], which determine dune initiation and shape [62]. Furthermore, local and regional variation in biophysical attributes of the beach and occurrence of dune-building species will determine the dune shape and type that can be built in each site [65].

Second, different activities that regularly occur on urban beaches might (or will be) limited. For instance, using machinery for litter removal in the presence of a mosaic of incipient dunes will be complicated at best. Here, new windows of opportunity to improve beach management might arise. For aesthetic, human health, and economic reasons, urbanized and heavily used beaches need to have cleaning activities that include litter and natural debris. As a result, cleaning machinery is frequently used. However, evidence has shown that heavy machines can have deleterious effects on the beach flora and fauna because the habitat is destroyed (compacted), and plants and animals are killed [84,85]. New alternatives for beach cleaning that are environmentally adequate could include manual cleaning $[84,86]$ as well as the reduction of beach littering and litter generation. This approach needs environmental education of beachgoers, staff training, adequate provision of waste receptacles, and fines for littering [84,87].

Other activities that are not compatible with the incipient dune strategy for social distancing would be trampling on coastal dunes and using off-road vehicles. There is increasing evidence of the negative impacts that trampling and vehicles have on the dunes and the local flora and fauna (see, for example, [88-91]). Damage is fast, while recovery slow. Consequently, these destructive activities should be either avoided altogether or 
consider beach zonation with areas designated for them, while others are kept safe from them. A zonation scheme in which the beach is divided into areas heavily used and areas moderately used allows the beach flora and fauna to develop on less disturbed habitats [92].

Third, the new beachscape must face the social perceptions and acceptance surrounding the implementation of these projects. Failure to comply with environmental regulations or encourage the population's involvement (stakeholders, staff, or visitors) is of great importance for the project's success [93]. For instance, [94] explored the perception of beachgoers to new management strategies aimed at protecting threatened bird species on urban beaches. Here, beachgoers reported reduced inconveniences induced by the conservation efforts because of high awareness and support of these actions. Similarly, beach preservation is frequently relevant to beachgoers. For example, they are willing to pay an annual fee to preserve the beach in Italy [95] and Australia [96]. In Mexico, [97] also found that tourists are willing to pay increased entrance fees at Mexican protected areas, including beaches, to support conservation actions. However, in other Mexican beaches with mostly national visitors, personal field observations by the authors (unpublished data) have shown that stakeholders and beachgoers prefer flattened beaches void of dunes and plants. In this case, environmental education programs would be necessary to deliver the benefits of the more natural beachscapes, which, besides promoting social distancing and human health, would also help with shoreline protection by mitigating erosion [98-100].

Indeed, the multidisciplinary collaboration between academia, stakeholders, decisionmakers, and beachgoers is necessary to achieve new nature-based alternatives for beach management, even though the perceptions on the costs and benefits would probably differ [101]. New pilot designs would be necessary to test the effectiveness of this proposal, considering the social, economic, and environmental aspects that the proposal implies.

Finally, the new nature-based solution for social distancing and climate-change adaptation should be accompanied by awareness campaigns on the relevance of protecting coastal dunes and their vegetation. These initiatives are crucial to engaging stakeholders, local inhabitants, and visitors from non-coastal regions in a better understanding of why we need to avoid trampling and driving over dunes.

\section{Conclusions}

Human health and well-being are closely linked to ecosystem health and ecosystem services [102]. The new pandemic conditions and the inability to predict its duration have forced human society to develop new strategies to take care of ourselves and our surrounding environment, to maintain our health, jobs, economy, and the environment. The pandemic offers opportunities to design and eventually test new ad hoc schemes for coastal management. This paper presents a new management model for sandy beaches aimed at sun-sand-and-sea tourism that will help promote social distancing in a COVID-19 pandemic. The approach presented in the article is aimed to be beneficial for human health as well as the environment because natural materials are used, which will also help in dune restoration. As anti-epidemic measures cease, the new model of beachscape will be helpful in the sustainable development and environmental protection context that will, additionally, provide scenic beauty and coastal protection. We need to find new ways to enjoy the beach and associated activities and, possibly, move to a new status-quo that is healthier for everyone, including natural ecosystems. As with any new protocol, the nature-based solutions should be tested and corrected after creating a prototype.

Author Contributions: Conceptualization, P.M.-C., M.L.M., and D.L.; methodology, P.M.-C.; validation, P.M.-C.; formal analysis, P.M.-C.; investigation, P.M.-C., M.L.M., and D.L.; data curation, P.M.-C.; writing—original draft preparation, M.L.M.; writing-review and editing, P.M.-C. and D.L.; visualization, D.L.; funding acquisition, M.L.M. All authors have read and agreed to the published version of the manuscript.

Funding: This research was funded by CEMIE-Océano (CONACYT), grant number 249795.

Institutional Review Board Statement: Not applicable. 
Informed Consent Statement: Not applicable.

Data Availability Statement: Information on Mexican coastal dunes species is publicly available at: https: / / www.gbif.org/ dataset/3c089a4c-c5af-4fa0-b46f-1885036b82f4 (accessed on 10 May 2021).

Acknowledgments: The authors express their gratitude to the anonymous reviewers and the editors for their thorough comments and recommendations made on earlier versions of the manuscript.

Conflicts of Interest: The authors declare no conflict of interest. The funders had no role in the design of the study; in the collection, analyses, or interpretation of data; in the writing of the manuscript, or in the decision to publish the results.

\section{References}

1. Worldometer. Coronavirus Updates. Available online: https:/ /www.worldometers.info/ (accessed on 10 May 2021).

2. Campos, A.P.; Cuevas, P.D. Aproximaciones a la capacidad de acogida de las playas como recurso turístico en tiempos de la COVID-19: El caso de la costa atlántica andaluza. Bol. Asoc. Geógr. Esp. 2021. [CrossRef]

3. Epelde, I.; Liria, P.; de Santiago, I.; Garnier, R.; Uriarte, A.; Picón, A.; Galdrán, A.; Arteche, J.A.; Lago, A.; Corera, Z.; et al. Beach carrying capacity management under Covid-19 era on the Basque Coast by means of automated coastal videometry. Ocean Coast. Manag. 2021, 208, 105588. [CrossRef]

4. Zielinski, S.; Botero, C.M. Beach Tourism in Times of COVID-19 Pandemic: Critical Issues, Knowledge Gaps and Research Opportunities. Int. J. Environ. Res. Public Health 2020, 17, 7288. [CrossRef] [PubMed]

5. Semarnat. Guía de Recomendaciones para un Retorno Ambientalmente Responsable del Ecoturismo y el Turismo de Sol y Playa; Secretaría de Medio Ambiente y Recursos Naturales, Subsecretaría de Fomento y Normatividad Ambiental, Direccioón General de Fomento Ambiental, Urbano y Turístico y Dirección General de Zona Federal Marítimo Terrestre y Ambientes Costeros: Mexico City, Mexico, 2020; p. 64.

6. BCC Travel. You Might Need a Reservation for the Beach This Summer. Available online: https://edition.cnn.com/travel/ article/spanish-beach-reservations/index.html (accessed on 19 April 2021).

7. Dominioni, I. Social Distancing and Booking Apps: What to Expect on Italian Beaches This Summer. Available online: https:/ / www.forbes.com/sites/irenedominioni/2020/07/10/social-distancing-and-booking-apps-what-to-expect-on-italianbeaches-this-summer/?sh=58a3b51521a5 (accessed on 20 April 2021).

8. Bustos, M.L.; Zilio, M.I.; Ferrelli, F.; Piccolo, M.C.; Perillo, G.M.; Van Waarde, G.; Manstretta, G.M.M. Tourism in the COVID-19 context in mesotidal beaches: Carrying capacity for the 2020/2021 summer season in Pehuén Co, Argentina. Ocean Coast. Manag. 2021, 206, 105584. [CrossRef]

9. Anadolu Agency. Turkey Sees 30 Percent Rise in Number of Tourists. Hürriyet Daily News, 27 July 2018.

10. Daily Sabah. 'Glad to Be Back': Tourists Ready to Enjoy Safe Holidays in Turkey. Daily Sabah, 7 July 2020.

11. Soria, A. El Precio de Vivienda Vacacional Baja Entre el 5 y el 15\% en la Costa Norte de Valencia por la Covid. Available online: https:/ / valenciaplaza.com/caen-los-precios-en-torno-al-5-15-de-la-vivienda-vacacional-en-la-costa-valenciana (accessed on 7 May 2021).

12. Arribas, M. Canet Solo Exigirá Reservas de Parcelas en la Playa los Fines de Semana de Gran Afluencia. Available online: https:/ / www.levante-emv.com/comarcas/2020/06/30/canet-exigira-reservas-parcelas-playa-11265955.html (accessed on 7 May 2021).

13. Campos, E.H. Acapulco inicia el 2018 con 98.4 de ocupación hotelera. El Sol de México, 1 January 2018.

14. Aristegui Noticias. Restringen acceso a playas de Guerrero para evitar propagación del Covid-19. Aristegui Noticias, 2 April 2020.

15. Montagna, M.; Diella, G.; De Giglio, O.; Triggiano, F.; Carlucci, M.; Carpagnano, F.; Caggiano, G. Can beaches and bathing environments represent a risk of spreading COVID-19? Ann. Igeni 2020, 32, 593-596. [CrossRef]

16. Barcala-Furelos, R.; Aranda-García, S.; Abelairas-Gómez, C.; Martínez-Isasi, S.; López-Mesa, F.; Oleagordia-Aguirre, A.; PalaciosAguilar, J.; Szpilman, D. Recomendaciones de salud laboral para socorristas ante emergencias acuáticas en la era Covid-19: Prevención, rescate y reanimación. Rev. Esp. Salud Pública 2020, 94, e202006074. [PubMed]

17. Crespí-Rotger, S.; Ordóñez-Iriarte, J.M. COVID-Higiene del agua, climatizacioón y saneamiento en tiempos del COVID-19: Problemas sobre problemas. Rev. Salud Ambient. 2020, 20, 21-29.

18. Lima, G.H.V.; Guimarães, P.L.; Baboghluian, M. Covid-19 and surfing: Problems, strategies and solutions for surfers. Rev. Bras. Med. Esporte 2021, 27, 11-15. [CrossRef]

19. Clark, M. Signs, beaches and bodies in pandemic times. Media Int. Aust. 2021, 178, 8-15. [CrossRef]

20. Ardusso, M.; Forero-López, A.; Buzzi, N.; Spetter, C.; Fernández-Severini, M. COVID-19 pandemic repercussions on plastic and antiviral polymeric textile causing pollution on beaches and coasts of South America. Sci. Total. Environ. 2021, 763, 144365. [CrossRef]

21. Okuku, E.; Kiteresi, L.; Owato, G.; Otieno, K.; Mwalugha, C.; Mbuche, M.; Gwada, B.; Nelson, A.; Chepkemboi, P.; Achieng, Q.; et al. The impacts of COVID-19 pandemic on marine litter pollution along the Kenyan Coast: A synthesis after 100 days following the first reported case in Kenya. Mar. Pollut. Bull. 2021, 162, 111840. [CrossRef] 
22. Cowles, D.L.; Onthank, K.L. Providing interactive and field laboratories while teaching university marine biology classes in an era of COVID-19. Invertebr. Biol. 2021, 140, e12323. [CrossRef]

23. Quesada-Rodríguez, C.; Orientale, C.; Diaz-Orozco, J.; Sellés-Ríos, B. Impact of 2020 COVID-19 lockdown on environmental education and leatherback sea turtle (Dermochelys coriacea) nesting monitoring in Pacuare Reserve, Costa Rica. Biol. Conserv. 2021, 255, 108981. [CrossRef]

24. Okyere, I.; Chuku, E.O.; Ekumah, B.; Angnuureng, D.B.; Boakye-Appiah, J.K.; Mills, D.J.; Babanawo, R.; Asare, N.K.; Aheto, D.W.; Crawford, B. Physical distancing and risk of COVID-19 in small-scale fisheries: A remote sensing assessment in coastal Ghana. Sci. Rep. 2020, 10, 1-13. [CrossRef]

25. Loizia, P.; Voukkali, I.; Chatziparaskeva, G.; Navarro-Pedreño, J.; Zorpas, A. Measuring the Level of Environmental Performance on Coastal Environment before and during the COVID-19 Pandemic: A Case Study from Cyprus. Sustainability 2021, 13, 2485. [CrossRef]

26. Gilby, B.L.; Henderson, C.J.; Olds, A.D.; Ballantyne, J.A.; Bingham, E.L.; Elliott, B.B.; Jones, T.R.; Kimber, O.; Mosman, J.D.; Schlacher, T.A. Potentially negative ecological consequences of animal redistribution on beaches during COVID-19 lockdown. Biol. Conserv. 2021, 253, 108926. [CrossRef]

27. Carvache-Franco, O.; Carvache-Franco, M.; Carvache-Franco, W. Coastal and marine topics and destinations during the COVID-19 pandemic in Twitter's tourism hashtags. Tour. Hosp. Res. 2021. [CrossRef]

28. Jeon, C.-Y.; Yang, H.-W. The structural changes of a local tourism network: Comparison of before and after COVID-19. Curr. Issues Tour. 2021, 16, 1-15. [CrossRef]

29. Roy, G.; Sharma, S. Analyzing one-day tour trends during COVID 19 disruption-Applying push and pull theory and text mining approach. Tour. Recreat. Res. 2020, 1-16. [CrossRef]

30. Kane, B.; Zajchowski, C.A.; Allen, T.R.; McLeod, G.; Allen, N.H. Is it safer at the beach? Spatial and temporal analyses of beachgoer behaviors during the COVID-19 pandemic. Ocean Coast. Manag. 2021, 205, 105533. [CrossRef]

31. Pereira, L.C.C.; Felix, R.C.d.S.; Dias, A.B.B.; Pessoa, R.M.C.; da Silva, B.R.P.; Baldez, C.A.D.C.; da Costa, R.M.; da Silva, T.S.; Assis, L.F.d.S.; Jimenez, J.A. Beachgoer perceptions on health regulations of COVID-19 in two popular beaches on the Brazilian Amazon. Ocean Coast. Manag. 2021, 206, 105576. [CrossRef] [PubMed]

32. Pranzini, E. Pandemics and coastal erosion in Tuscany (Italy). Ocean Coast. Manag. 2021, 208, 105614. [CrossRef]

33. Milanes, C.B.; Montero, O.P.; Cabrera, J.A.; Cuker, B. Recommendations for coastal planning and beach management in Caribbean insular states during and after the COVID-19 pandemic. Ocean Coast. Manag. 2021, 208, 105575. [CrossRef]

34. Krupskaia, A. Jaguares, Cocodrilos y Monos Regresan a Playas Mexicanas Ante Ausencia Humana. Available online: https: / / cnnespanol.cnn.com/video/fauna-animales-quintana-roo-caribe-mexicano-humanos-coronavirus-dia-tierra-pkgkrupskaia-alis-perspectivas-mexico/ (accessed on 20 April 2021).

35. Ormaza-González, F.; Castro-Rodas, D. COVID-19 Impacts on beaches and coastal water pollution: Management proposals post-pandemic. Preprints 2020, 2020060186. [CrossRef]

36. Zambrano-Monserrate, M.A.; Ruano, M.A.; Sanchez-Alcalde, L. Indirect effects of COVID-19 on the environment. Sci. Total. Environ. 2020, 728, 138813. [CrossRef] [PubMed]

37. Rowe, B.; Canosa, A.; Drouffe, J.; Mitchell, J. Simple quantitative assessment of the outdoor versus indoor airborne transmission of viruses and COVID-19. Environ. Res. 2021, 198, 111189. [CrossRef] [PubMed]

38. Higgins-Desbiolles, F. Socialising tourism for social and ecological justice after COVID-19. Tour. Geogr. 2020, 22, 610-623. [CrossRef]

39. Temmerman, S.; Meire, P.; Bouma, T.J.; Herman, P.M.J.; Ysebaert, T.; De Vriend, H.J. Ecosystem-based coastal defence in the face of global change. Nat. Cell Biol. 2013, 504, 79-83. [CrossRef]

40. Martínez, M.L.; Silva, R.; López-Portillo, J.; Feagin, R.A.; Martínez, E. Coastal Ecosystems as an Ecological Membrane. J. Coast. Res. 2020, 95, 97-101. [CrossRef]

41. Azuz-Adeath, I. Cetys Governance and Management of Coasts and Ocean in the face of uncertainty. A Guide for Decision Makers. Gov. Manag. Coasts Ocean Face Uncertain. Guide Decis. Mak. 2020, 193-216. [CrossRef]

42. Padilla-Lugo, J.; González-Hernández, J. Organizational citizenship behavior and job satisfaction within hosting sector employees in Zacatecas, México. Estud. Perspect. Tur. 2020, 29, 605-626.

43. Reglamento para el uso y aprovechamiento del Mar Territorial, Vías Navegables, Playas, Zona Federal Marítimo Terrestre y Terrenos Ganados al Mar. Available online: https://www.profepa.gob.mx/innovaportal/file/3668/1/reglamento_zofemat.pdf (accessed on 10 May 2021).

44. Tribune Media Services. Protestan con Picnic Masivo por Prohibir a Visitantes Locales el uso de Playa del Carmen. Available online: https: / / www.chicagotribune.com/espanol/sns-es-protestan-por-privatizacion-de-playas-20200224-k2fi4tvo6fctdbdu6 ypik7qwcm-story.html (accessed on 20 April 2021).

45. Playas de Mexico. Playas de México por Estado. Available online: https://www.playasmexico.com.mx/playas-de-mexico-porestado/ (accessed on 9 May 2021).

46. Propín-Frejomil, E.; Sánchez-Crispín, Á. Tipología de los destinos turísticos preferenciales en México. Cuad. Tur. 2007. [CrossRef]

47. Soto, E.; Botero, C.; Milanés, C.; Rodríguez-Santiago, A.; Palacios-Moreno, M.; Díaz-Ferguson, E.; Velázquez, Y.; Abbehusen, A.; Guerra-Castro, E.; Simoes, N.; et al. How does the beach ecosystem change without tourists during COVID-19 lockdown? Biol. Conserv. 2021, 255, 108972. [CrossRef] 
48. Ley General de Bienes Nacionales. Available online: http:/ / www.diputados.gob.mx/LeyesBiblio/pdf/267_211020.pdf (accessed on 10 May 2021).

49. Martínez, M.L.; Moreno-Casasola, P.; Espejel, I.; Jiménez- Orocio, O.; Infante-Mata, D. Diagnóstico General de las Dunas Costeras de México; Comisión Nacional Forestal: Mexico City, Mexico, 2014.

50. Moreno-Casasola, P.; Espejel, I.; Castillo, S.; Castillo-Campos, G.; Durán, R.; Pérez-Navarro, J.; León, J.; Olmsted, I.; Trejo-Torres, J. Flora de los ambientes arenosos y rocosos de las costas de México. In La Diversidad Biológica de Iberoamérica; Halffter, G., Ed.; Acta Zoologica Mexicana; Instituto de Ecología: Veracruz, Mexico, 1998; Volume II, pp. 177-258.

51. Jiménez-Orocio, O.; Espejel, I.; Martínez, M.L. La investigación científica sobre dunas costeras de México: Origen, evolución y retos. Rev. Mex. Biodivers. 2015, 86, 486-507. [CrossRef]

52. Espejel, I.; Jiménez-Orocio, O.; Castillo-Campos, G.; Garcillán, P.P.; Álvarez, L.; Castillo-Argüero, S.; Durán, R.; Ferrer, M.; Infante-Mata, D.; Iriarte, S.; et al. Flora en playas y dunas costeras de México. Acta Bot. Mex. 2017, 121, 39-81. [CrossRef]

53. Johnson, A.F. A Survey of the Strand and Dune Vegetation Along the Pacific and Southern Gulf Coasts of Baja California, Mexico. J. Biogeogr. 1977, 4, 83. [CrossRef]

54. Johnson, A.F. Dune Vegetation Along the Eastern Shore of the Gulf of California. J. Biogeogr. 1982, 9, 317. [CrossRef]

55. Martinez, M.L.; Moreno-Casasola, P. Effects of burial by sand on seedling growth and survival in six tropical sand dune species from the Gulf of Mexico. J. Coast. Res. 1996, 12, 406-419.

56. Sloss, C.R.; Shepherd, M.; Hesp, P. Coastal Dunes: Geomorphology. Nat. Educ. Knowl. 2012, 3, 21.

57. Hesp, P. Foredunes and blowouts: Initiation, geomorphology and dynamics. Geomorphology 2002, 48, 245-268. [CrossRef]

58. Ley-Vega De Seoane, C.; Gallego-Fernández, J.B.; Vidal-Pascual, C. Manual de Restauración de Dunas Costeras; Ministerio de Medio Ambiente, Dirección General de Costas (MAGRAMA): Santa Cruz de Tenerife, Spain, 2007.

59. Mullins, E.; Moore, L.J.; Goldstein, E.B.; Jass, T.; Bruno, J.; Vinent, O.D. Investigating dune-building feedback at the plant level: Insights from a multispecies field experiment. Earth Surf. Process. Landf. 2019, 44, 1734-1747. [CrossRef]

60. Young, D.R.; Brantley, S.T.; Zinnert, J.C.; Vick, J.K. Landscape position and habitat polygons in a dynamic coastal environment. Ecosphere 2011, 2, art71. [CrossRef]

61. Grafals-Soto, R.; Nordstrom, K. Sand Fences in the Coastal Zone: Intended and Unintended Effects. Environ. Manag. 2009, 44, 420-429. [CrossRef] [PubMed]

62. Charbonneau, B.R.; Dohner, S.M.; Wnek, J.P.; Barber, D.; Zarnetske, P.; Casper, B.B. Vegetation effects on coastal foredune initiation: Wind tunnel experiments and field validation for three dune-building plants. Geomorphology 2021, 378, 107594. [CrossRef]

63. Borsje, B.W.; van Wesenbeeck, B.K.; Dekker, F.; Paalvast, P.; Bouma, T.J.; van Katwijk, M.M.; de Vries, M.B. How ecological engineering can serve in coastal protection. Ecol. Eng. 2011, 37, 113-122. [CrossRef]

64. Van Der Putten, W.H.; Yeates, G.W.; Duyts, H.; Reis, C.S.; Karssen, G. Invasive plants and their escape from root herbivory: A worldwide comparison of the root-feeding nematode communities of the dune grass Ammophila arenaria in natural and introduced ranges. Biol. Invasions 2005, 7, 733-746. [CrossRef]

65. Hacker, S.D.; Jay, K.R.; Cohn, N.; Goldstein, E.B.; Hovenga, P.A.; Itzkin, M.; Moore, L.J.; Mostow, R.S.; Mullins, E.V.; Ruggiero, P. Species-Specific Functional Morphology of Four US Atlantic Coast Dune Grasses: Biogeographic Implications for Dune Shape and Coastal Protection. Diversity 2019, 11, 82. [CrossRef]

66. Lonard, R.I.; Judd, F.W. The Biological Flora of Coastal Dunes and Wetlands: Croton punctatus N. von Jacquin. J. Coast. Res. 2009, 251, 23-29. [CrossRef]

67. Lonard, R.I.; Judd, F.W. The Biological Flora of Coastal Dunes and Wetlands: Panicum amarum S. Elliott and Panicum amarum S. Elliott var. amarulum (A.S. Hitchcock and M.A. Chase) P. Palmer. J. Coast. Res. 2011, 27, 233-242. [CrossRef]

68. Lonard, R.I.; Judd, F.W.; Stalter, R. Biological Flora of Coastal Dunes and Wetlands: Uniola paniculata L. J. Coast. Res. 2011, 276, 984-993. [CrossRef]

69. Lonard, R.I.; Judd, F.W.; Stalter, R. The biological flora of coastal dunes and wetlands: Sporobolus virginicus (C. Linnaeus) K. Kunth. J. Coast. Res. 2013, 29, 706-716. [CrossRef]

70. Lonard, R.I.; Judd, F.W.; Stalter, R. The Biological Flora of Coastal Dunes and Wetlands: Solidago sempervirens L. and Solidago sempervirens L. subsp. mexicana (L.) Semple. J. Coast. Res. 2015, 316, 1512-1520. [CrossRef]

71. Packham, J.R.; Willis, A.J. Ecology of Dunes, Salt Marsh and Shingle; Chapman \& Hall: London, UK; University Press: Cambridge, UK, 1997.

72. Moreno-Casasola, P.; Travieso-Bello, A.C. Playas y Dunas. In Estrategias para el Manejo Integral de la Zona Costera: Un Enfoque Municipal; Moreno-Casasola, P., Peresbarbosa, E., Travieso-Bello, A.C., Eds.; Instituto de Ecología, A.C., Comisión Nacional de Areas Naturales Protegidas, SEMARNAT, Gobierno del Estado de Veracruz: Veracruz, Mexico, 2006; pp. 121-149.

73. Luijendijk, A.; Hagenaars, G.; Ranasinghe, R.; Baart, F.; Donchyts, G.; Aarninkhof, S. The State of the World's Beaches. Sci. Rep. 2018, 8, 1-11. [CrossRef]

74. Zhang, K.; Douglas, B.C.; Leatherman, S.P. Global Warming and Coastal Erosion. Clim. Chang. 2004, 64, 41-58. [CrossRef]

75. Silva, R.; Martinez, M.L.; Hesp, P.A.; Catalan, P.; Osorio, A.F.; Martell, R.; Fossati, M.; da Silva, G.M.; Mariño-Tapia, I.; Pereira, P.D.S.; et al. Present and Future Challenges of Coastal Erosion in Latin America. J. Coast. Res. 2014, 71, 1-16. [CrossRef]

76. Bradshaw, C.J.A.; Ehrlich, P.R.; Beattie, A.; Ceballos, G.; Crist, E.; Diamond, J.; Dirzo, R.; Ehrlich, A.H.; Harte, J.; Harte, M.E.; et al. Underestimating the Challenges of Avoiding a Ghastly Future. Front. Conserv. Sci. 2021, 1, 9. [CrossRef] 
77. Mentaschi, L.; Vousdoukas, M.I.; Pekel, J.-F.; Voukouvalas, E.; Feyen, L. Global long-term observations of coastal erosion and accretion. Sci. Rep. 2018, 8, 1-11. [CrossRef]

78. Salgado, K.; Martinez, M.L. Is ecosystem-based coastal defense a realistic alternative? Exploring the evidence. J. Coast. Conserv. 2017, 21, 837-848. [CrossRef]

79. Everard, M.; Jones, L.; Watts, B. Have we neglected the societal importance of sand dunes? An ecosystem services perspective. Aquat. Conserv. Mar. Freshw. Ecosyst. 2010, 20, 476-487. [CrossRef]

80. Comisión Nacional para el Conocimiento y Uso de la Biodiversidad (CONABIO). Sistema de Monitoreo de Manglares de México (SMMM). Available online: https:/ / www.biodiversidad.gob.mx/monitoreo/smmm (accessed on 9 May 2021).

81. Silva, R.; Oumeraci, H.; Martínez, M.L.; Chávez, V.; Lithgow, D.; van Tussenbroek, B.I.; van Rijswick, H.F.M.W.; Bouma, T.J. Ten Commandments for Sustainable, Safe, and W/Healthy Sandy Coasts Facing Global Change. Front. Mar. Sci. 2021, 8, 126. [CrossRef]

82. Nordstrom, K.F.; Jackson, N.L.; Bruno, M.S.; De Butts, H.A. Municipal initiatives for managing dunes in coastal residential areas: A case study of Avalon, New Jersey, USA. Geomorphology 2002, 47, 137-152. [CrossRef]

83. Nordstrom, K.F.; Jackson, N.L.; Kraus, N.C.; Kana, T.W.; Bearce, R.; Bocamazo, L.M.; Young, D.R.; De Butts, H.A. Enhancing geomorphic and biologic functions and values on backshores and dunes of developed shores: A review of opportunities and constraints. Environ. Conserv. 2011, 38, 288-302. [CrossRef]

84. Zielinski, S.; Botero, C.M.; Yanes, A. To clean or not to clean? A critical review of beach cleaning methods and impacts. Mar. Pollut. Bull. 2019, 139, 390-401. [CrossRef] [PubMed]

85. Lithgow, D.; Martínez, M.; Gallego-Fernández, J.; Hesp, P.; Flores, P.; Gachuz, S.; Rodríguez-Revelo, N.; Jiménez-Orocio, O.; Mendoza-González, G.; Álvarez-Molina, L. Linking restoration ecology with coastal dune restoration. Geomorphology 2013, 199, 214-224. [CrossRef]

86. Morton, J.K.; Ward, E.J.; De Berg, K.C. Potential Small- and Large-Scale Effects of Mechanical Beach Cleaning on Biological Assemblages of Exposed Sandy Beaches Receiving Low Inputs of Beach-Cast Macroalgae. Chesap. Sci. 2015, 38, 2083-2100. [CrossRef]

87. Eastman, L.B.; Núñez, P.; Crettier, B.; Thiel, M. Identification of self-reported user behavior, education level, and preferences to reduce littering on beaches-A survey from the SE Pacific. Ocean Coast. Manag. 2013, 78, 18-24. [CrossRef]

88. Šilc, U.; Caković, D.; Küzmič, F.; Stešević, D. Trampling impact on vegetation of embryonic and stabilised sand dunes in Montenegro. J. Coast. Conserv. 2017, 21, 15-21. [CrossRef]

89. Hesp, P.; Schmutz, P.; Martinez, M.; Driskell, L.; Orgera, R.; Renken, K.; Revelo, N.A.R.; Orocio, O.A.J. The effect on coastal vegetation of trampling on a parabolic dune. Aeolian Res. 2010, 2, 105-111. [CrossRef]

90. Farris, E.; Pisanu, S.; Ceccherelli, G.; Filigheddu, R. Human trampling effects on Mediterranean coastal dune plants. Plant Biosyst. Int. J. Deal. Asp. Plant Biol. 2013, 147, 1043-1051. [CrossRef]

91. Kutiel, P.; Eden, E.; Zhevelev, Y. Effect of experimental trampling and off-road motorcycle traffic on soil and vegetation of stabilized coastal dunes, Israel. Environ. Conserv. 2000, 27, 14-23. [CrossRef]

92. Defeo, O.; McLachlan, A.; Schoeman, D.S.; Schlacher, T.; Dugan, J.; Jones, A.; Lastra, M.; Scapini, F. Threats to sandy beach ecosystems: A review. Estuar. Coast. Shelf Sci. 2009, 81, 1-12. [CrossRef]

93. Chávez, V.; Lithgow, D.; Losada, M.; Silva-Casarin, R. Coastal green infrastructure to mitigate coastal squeeze. J. Infrastruct. Preserv. Resil. 2021, 2, 1-12. [CrossRef]

94. Maguire, G.S.; Rimmer, J.M.; Weston, M.A. Stakeholder Perceptions of Threatened Species and Their Management on Urban Beaches. Animals 2013, 3, 1002-1020. [CrossRef]

95. Rodella, I.; Madau, F.; Mazzanti, M.; Corbau, C.; Carboni, D.; Utizi, K.; Simeoni, U. Willingness to pay for management and preservation of natural, semi-urban and urban beaches in Italy. Ocean Coast. Manag. 2019, 172, 93-104. [CrossRef]

96. Ardeshiri, A.; Swait, J.; Heagney, E.; Kovac, M. Willingness-to-pay for coastline protection in New South Wales: Beach preservation management and decision making. Ocean Coast. Manag. 2019, 178, 104805. [CrossRef]

97. Witt, B. Tourists' Willingness to Pay Increased Entrance Fees at Mexican Protected Areas: A Multi-Site Contingent Valuation Study. Sustainability 2019, 11, 3041. [CrossRef]

98. Silva, R.; Martinez, M.L.; Odériz, I.; Mendoza, E.; Feagin, R. Response of vegetated dune-beach systems to storm conditions. Coast. Eng. 2016, 109, 53-62. [CrossRef]

99. Maximiliano-Cordova, C.; Salgado, K.; Martínez, M.L.; Mendoza, E.; Silva, R.; Guevara, R.; Feagin, R.A. Does the Functional Richness of Plants Reduce Wave Erosion on Embryo Coastal Dunes? Chesap. Sci. 2019, 42, 1730-1741. [CrossRef]

100. Feagin, R.; Furman, M.; Salgado, K.; Martinez, M.; Innocenti, R.; Eubanks, K.; Figlus, J.; Huff, T.; Sigren, J.; Silva, R. The role of beach and sand dune vegetation in mediating wave run up erosion. Estuar. Coast. Shelf Sci. 2019, 219, 97-106. [CrossRef]

101. Lithgow, D.; Martinez, M.L.; Silva, R.; Geneletti, D.; Gallego-Fernández, J.B.; Cerdán, C.R.; Mendoza, E.; Jermain, A. Ecosystem Services to Enhance Coastal Resilience in Mexico: The Gap between the Perceptions of Decision-Makers and Academics. J. Coast. Res. 2017, 77, 116-126. [CrossRef]

102. Sandifer, P.A.; Sutton-Grier, A.E.; Ward, B.P. Exploring connections among nature, biodiversity, ecosystem services, and human health and well-being: Opportunities to enhance health and biodiversity conservation. Ecosyst. Serv. 2015, 12, 1-15. [CrossRef] 